\title{
Analisis Kemampuan Motorik Halus dan Kreativitas pada Anak Usia Dini melalui Kegiatan Kolase
}

\author{
Zherly Nadia Wandi ${ }^{\otimes_{1}}$, Farida Mayar ${ }^{2}$ \\ Pendidikan Anak Usia Dini, Universitas Negeri Padang \\ DOI: $\underline{10.31004 / \text { obsesi.v4i1.347 }}$
}

\begin{abstract}
Abstrak
Perkembangan motorik halus sangat penting bagi perkembangan anak secara keseluruhan . Anak usia taman kanak-kanak masih sering mengalami kesulitan dalam menggerakkan jarijarinya untuk kegiatan seperti menggunting, menggambar, merobek, melipat, menyusun dan mengisi pola dengan menempelkan benda-benda kecil. Penelitian ini bertujuan untuk mendeskripsikan kemampuan motorik halus dan kreativitas pada anak usia dini melalui kegiatan kolase. Metode penelitian yang digunakan adalah kajian pustaka yang dilakukan dengan mengumpulkan data-data atau berdasarkan karya tulis ilmiah yang menghubungkan penelitian dengan literatur yang ada untuk memecahkan suatu masalah. Metode pengumpulan data pustaka dengan membaca dan mencatat serta mengelola bahan penelitian lalu menyimpulkan bahan penelitian. Hasil penelitian yang didapat bahwa perkembangan kemampuan motorik halus dan kreativitas pada anak usia dini memerlukan koordinasi mata dan tangan, seperti menyusun, merobek dan menempel yang dilakukan melalui kegiatan kolase.
\end{abstract}

Kata Kunci: kemampuan motorik halus; kreativitas; kegiatan kolase.

\begin{abstract}
Fine motor development is very important for overall child development. Kindergarten age children still often have difficulty in moving their fingers for activities such as cutting, drawing, tearing, folding, arranging and filling patterns by attaching small objects. This study aims to describe fine motor skills and creativity in early childhood through collage activities. The research method used is a literature review conducted by collecting data or based on scientific papers that connect research with existing literature to solve a problem. Library data collection methods by reading and recording and managing research materials and then concluding research materials. The results of the study found that the development of fine motor skills and creativity in early childhood requires eye and hand coordination, such as arranging, tearing and sticking which is done through collage activities.
\end{abstract}

Keywords: fine motor skill; creativity; collage activities.

Copyright (c) 2019 Zherly Nadia Wandi, Farida Mayar

$\triangle$ Corresponding author :

Email Address : zherlynadia@gmail.com (Padang, Sumatera Barat, Indonesia)

Received 26 November 2019, Accepted 5 December 2019, Published 9 December 2019 


\section{PENDAHULUAN}

Pendidikan merupakan salah satu kebutuhan hidup yang sangat diperlukan untuk mengembangkan kompetensi manusia melalui pembelajaran. Pendidikan mencakup proses hidup dan interaksi manusia dengan lingkungannya dalam rangka mengembangkan seluruh potensi yang dimiliki sesuai dengan tahapan perkembangan agar berjalan optimal. Prayitno (2009:203) menjelaskan bahwa pendidikan merupakan suatu wahana bagi pengembangan manusia, yang mana pendidikan menjadi media bagi pemuliaan kemanusiaan.

Pendidikan bagi anak usia dini adalah berupa pemberian upaya yang dilakukan untuk membimbing, mengasuh, menstimulasi sehingga akan menghasilkan kemampuan dan keterampilan anak. Menurut Siswanto (2008:2), "Pendidikan anak memang harus dimulai sejak dini agar anak bisa mengembangkan potensinya secara optimal dengan tujuan agar anak-anak yang mengikuti PAUD menjadi lebih mandiri, disiplin, dan mudah diarahkan untuk menyerap ilmu pengetahuan secara optimal".

Anak usia dini berada pada rentang usia 0 sampai dengan 6 tahun, anak usia taman kanak-kanak berada pada rentang usia 4-6 tahun. Batasan ini sesuai dengan batasan menurut Undang-undang Nomor 20 Tahun 2003 Tentang Sistem Pendidikan Nasional yang menyatakan bahwa "taman kanak-kanak merupakan pendidikan formal pada jalur pendidikan anak usia dini yang mendidik anak usia 4-6 tahun". (Suryana, 2011:31-32).

Tujuan pendidikan taman kanak-kanak adalah untuk membantu meletakkan dasar untuk mengembangan sikap, perilaku, pengakuan, keterampilan dan kreativitas yang nantinya akan diperlukan anak untuk pertumbuhan dan perkembangannya. Pendidikan anak usia dini ini diselenggarakan dengan tujuan untuk memfasilitasi seluruh kemampuan anak, sehingga lembaga pendidikan anak usia dini perlu untuk menyediakan berbagai kegiatan yang mendukung tumbuh kembang anak dari berbagai aspek perkembangan anak yaitu kognitif, bahasa, fisik motorik, sosial emosional, agama moral dan seni.

Menurut berbagai penelitian di bidang neurologi terbukti bahwa 50\% kecerdasan anak terbentuk dalam kurun waktu 4 tahun pertama. Lalu setelah anak usia 8 tahun perkembangan otaknya mencapai $80 \%$ dan pada usia 18 tahun mencapai $100 \%$ (Suyanto, 2005: 6).

Selain itu Suryana (2018:159) mendeskripsikan perkembangan motorik anak khususnya motorik halus usia 4-5 adalah sebagai berikut 1) Menggambar sesuatu yang berarti bagi anak; 2) Menggunakan gerakan jemari selama permainan jari; 3) Menjiplak gambar kotak; 4) Mewarnai dengan garis-garis; 5) Memotong bentuk-bentuk sederhana seperti geometri. Perkembangan motorik halus pada anak usia ini akan dapat berpengaruh pada kreativitas anak tersebut.

Menurut Susanto (2011:164) motorik halus adalah gerakan halus yang melibatkan bagian-bagian tertentu saja yang dilakukan oleh otot-otot kecil saja, karena tidak memerlukan tenaga tetapi motorik halus memerlukan koordinasi yang cermat dan tepat dengan penuh kesabaran serta konsentrasi. Dengan semakin baik perkembangan motorik halusnya, anak semakin dapat berkreasi, seperti menggunting kertas dengan hasil guntingan yang lurus maupun zig zag, menggunakan klip untuk menyatukan dua lembar kertas, menjahit pola, menganyam kertas-kertas. Namun, tidak semua anak memiliki kematangan untuk menguasai kemampuan ini pada tahap yang sama.

Berkaitan dengan perkembangan kemampuan motorik halus yang sering kali terjadi pada anak usia dini khususnya taman kanak-kanak bahwa anak masih mengalami kesulitan dalam menggerakkan jari-jarinya untuk kegiatan seperti menggunting, mengambar, melipat, dan mengisi pola dengan nempelkan benda-benda kecil, dll. Hal ini disebabkan karena beberapa hal yang menjadi penyebab terjadinya permasalahan tersebut seperti media yang terbatas, anak belum bisa memegang gunting dengan benar, belum bisa menempel sesuai pola, maupun metode dan strategi yang kurang tepat dalam pembelajarannya. 
DOI: 10.31004/obsesi.v4i1.347

Berdasarkan hasil pengamatan yang dilakukan oleh peneliti di Taman Kanak-Kanak Islam Budi Mulia, pengembangan motorik halus dan kreativitas dilakukan dengan kegiatan mencocok, melukis, menulis, melipat, meronce, kolase dll. tetapi masih diperlukan media dan kegiatan yang lebih inovatif dan bahan-bahan yang lebih menarik. Kegiatan yang cocok atau sesuai dengan permasalahan yang terjadi dalam pengembangan motorik halus dan kreativitas yaitu melalui kegiatan kolase yang kegiatannya sangat menarik dan inovatif yang memerlukan koordinasi mata dan tangan yang baik. Kegiatan kolase sangat berkaitan dengan perkembangan motorik halus anak, karena keterampilan motorik halus (fine motor skill) merupakan keterampilan-keterampilan yang memerlukan untuk mengontrol otot-otot kecil/halus untuk mencapai pelaksanaan keterampilan yang berhasil.

(Muarifah \& Nurkhasanah, 2019) Berdasarkan penelitian dengan metode penelitian true experiment dengan judul "Pengaruh Kegiatan Kolase Terhadap Keterampilan Motorik Halus Anak" menemukan bahwa pemberian kegiatan kolase berpengaruh sangat signifikan terhadap perkembangan keterampilan motorik halus anak usia 5-6 tahun, sehingga kegiatan kolase dapat direkomendasikan sebagai alternatif untuk membantu meningkatkan keterampilan motorik halus anak.

(Handayani, Sumarno, \& Suharno, 2018) Berdasarkan hasil penelitian dengan metode pre-eksperimen dengan desain one-Group-pretest-posttest design dengan judul "Pengaruh Aktivitas Kolase Terhadap Keterampilan Motorik Halus Pada Anak Usia Dini Melalui Metode Bermain di TK Pembina Kabupaten Rembang Sri" Melalui analisis yang akan dilakukan, bahwa aktivitas kolase akan berpengaruh positif pada aktivitas guru dalam memilih kegiatan bagi anak untuk meningkatkan keterampilan motorik halus pada anak khususnya kelenturan jari jemari dengan metode bermain.

Dalam bidang seni barang bekas seperti kulit telur, majalah lama, koran bekas, pakaian, kardus, kaleng plastik kemasan, amapas kelapa dan daun-daun kering dapat digunakan untuk menghasilkan bermacam kreasi yang unik salah satunya dengan menggunakan kegiatan kolase.

Selain itu kegiatan kolase ini akan dapat mengembangkan kreativitas anak juga. kreativitas dalam pendidikan sangatlah diperlukan. Berkaitan dengan kreativitas ada beberapa permasalahan yang terdapat pada anak usia dini diantaranya anak belum bisa membuat sesuatu yang unik sesuai imajinasinya selalu seperti yang dicontohkan guru.

(Palintan \& Saria, 2018) Berdasarkan penelitian dengan metode kualitatif dengan judul "Penggunaan Media Kolase dalam Meningkatkan Kreativitas Anak" hasil penelitian menunjukkan bahwa kreativitas anak meningkat setelah dilakukan kegiatan kolase yaitu berada pada kriteria berkembang sangat baik, karena anak mengalami peningkatan setelah diberikan kegiatan kolase menggunakan bahan kertas, ampas kelapa dan memilih bahan dan warna yang cocok dan sesuai serta lancer dalam menempel.

Maka dari itu diperlukan solusi ataupun aternatif yang cocok terkait pembelajaran pada anak usia dini agar kemampuan motorik halus pada anak usia dini dapat dikembangkan dan kreativitas dapat dilakukan melalui kegiatan kolase. Maka dari itu, peneliti tertarik untuk melakukan penelitian tentang Analisis Kemampuan Motorik Halus dan Kreativitas pada Anak Usia Dini Melalui Kegiatan Kolase.

\section{Kreativitas Anak Usia Dini}

Mayesky (2009:4) mengemukakan bahwa kreativitas adalah cara berfikir dan bertindak atau membuat sesuatu yang asli untuk individu dan dihargai oleh orang atau lainnya. Carl Roger dan Abraham Maslow dalam Jamaris (2006:56-58) mengemukakan kreativitas sebagai salah satu aspek kepribadian yang berkaitan dengan aktualisasi diri. Mulyadi (2000:30) mengemukakan kreativitas dapat didefinisikan sebagai kemampuan untuk membuat kombinasi baru berdasarkan data, informasi atau unsur-unsur yang ada. Kreativitas juga bisa diartikan sebagai kemampuan yang mencerminkan kelancaran, keluwesan, dan orisinalitas dalam berfikir. Jadi dari gagasan diatas dapat disimpulkan, 
bahwa kreativitas merupakan kemampuan untuk mengembangkan, membuat sesuatu, memperkaya dan merincikan suatu gagasan.

\section{Kegiatan Kolase}

Kolase merupakan salah satu kegiatan latihan motorik halus dengan cara menyusun dan menempelkan potongan kertas yang berwarna-warni, pada sebuah gambar atau pola tertentu. Akibat melihat gambar atau pola tersebut, anak akan tertarik dan tidak lekas bosan, ia tertarik untuk memotong kertas kecil-kecil atau merobek kertas,lalu menempelkan potongan kertas sesuai dengan gambar yang diinginkan, dengan demikian tanpa disadari kegiatan seperti ini akan melatih motorik halus anak. Secara perlahan-lahan ketika anak menjimpit, mengelem dan menempel potongan kertas, koordinasi tangan akan terlatih dengan sendirinya.

Kolase dibuat menggunakan bahan-bahan yang nantinya akan diubah bentuknya menjadi karya kolase. Material yang digunakan dalam pembuatan kolase di Taman Kanakkanak menggunakan bahan baku yang sederhana dan tidak membahayakan bahkan menggunakan bahan bekas dan baham alam.. Bahan yang digunakan untuk berkreasi antara lain : bekas gelas minuman mineral, kertas berwarna, permen, penjepit baju, kancing baju, benang, dan lain-lain.

Kemudian ide bentuk karya yang akan diekspresikan. Dalam proses membuat karya kolase, yaitu dengan cara menggabungkan atau menyatukan barang-barang yang terdiri dari benda yang berbeda-beda hingga menjadi sebuah karya seni. Dalam proses pembuatan karya kolase materialnya harus disiapkan dahulu.

Agar kegiatan bermain anak memiliki makna dan tujuan dalam hubungannya dengan kolase maka pendidik perlu memiliki kreativitas dan berinovasi mencari atau menyediakan bahan dan alat yang sesuai dengan perkembangan anak. Untuk memotivasi anak dalam berkarya melalui kegiatan kolase, seorang pendidik harus mengembangkan dan memodifikasi bahan-bahan maupun alatnya sehingga dapat ditemukan hal-hal yang baru dalam menghasilkan karya kolase manual yang tepat digunakan sebagai meteri kegiatan. Kegiatan kolase untuk Anak Usia Dini tetap menggunakan prinsip dasar ilmu kolase.

\section{METODOLOGI}

Penelitian ini menggunakan kajian pustaka, kajian pustaka dalam suatu penelitian ilmiah adalah salah satu bagian penting dari keseluruhan langkah-langkah metode penelitian. Sanusi (2016:32) Penelitian kepustakaan atau library research, yakni kegiatan penelitian yang dilakukan dengan mengumpulkan data-data atau berdasarkan karya tulis ilmiah yang bertujuan dengan obyek penelitian atau pengumpulan datanya bersifat kepustakaan, atau telaah kemudian dilaksanakan untuk memecahkan suatu masalah dan mendalam terhadap bahan-bahan pustaka yang relevan.

Sebelum menelaah bahan pustaka, peneliti harus mengetahui terlebih dahulu secara pasti tentang dari sumber informasi ilmiah yang mana itu akan diperoleh. Adapun beberapa sumber yang digunakan antara lain; buku-buku teks, jurnal ilmiah, , hasil-hasil penelitian dalam bentuk skripsi, tesis, desertasi, dan internet, serta sumber-sumber lainnya yang relevan.

Ada 3 alasan mengapa menggunakan penelitian pustaka yaitu: 1) persoalan penelitian tersebut hanya bisa dijawab lewat penelitian pustaka, 2) studi pustaka diperlukan sebagai salah satu tahap tersendiri, yaitu studi pendahuluan untuk memahami lebih dalam gejala baru yang tengah berkembang di lapangan atau dalam masyarakat, 3) data pustaka tetap andal untuk menjawab persoalan penelitiannya. Dengan demikan, riset pustaka dengan cara memanfaatkan sumber perpustakaan untuk memperoleh data penelitiannya sehingga dengan riset pustaka dapat membatasi kegiatan hanya pada bahan- bahan koleksi perpustakaan tanpa memerlukan riset lapangan. 
DOI: $10.31004 /$ obsesi.v4i1.347

\section{HASIL DAN PEMBAHASAN}

\section{Hubungan Kegiatan Kolase dengan Kemampuan Motorik Halus Anak Usia Dini}

Penelitian yang mendukung bahwa peningkatan kemampuan motorik halus dapat didapat dari kegiatan kolase adalah penelitian yang dilakukan oleh (Widiastini, Raga, \& Kusmaryatni, 2014) yang membuktikan bahwa adanya peningkatan kemampuan motorik halus yang sangat signifikan. Hasil penelitiannya menyatakan bahwa dengan menerapkan metode pemberian tugas melalui kegiatan kolase berbantuan media alam dapat meningkatkan kemampuan motorik halus anak. Aspek kemampuan motorik halus yang diteliti berkaitan dengan kelompok otot dan saraf inilah yang nantinya mampu mengembangkan gerak motorik halus seperti meremas kertas, menyobek, menggambar, menempel, menggunting, dan sebagainya.

Kolase merupakan kegiatan pembelajaran di taman kanak-kanak yang dapat meningkatkan perkembangan motorik halus anak, sehingga dengan kegiatan kolase ini anak-anak dapat melatih kesabaran, ketelitian, kejelian, kebersamaan, dan terutama melatih koordinasi gerak tangan. Koordinasi gerak tangan anak perlu dilatih agar gerakan tangan anak terbiasa dengan hal-hal baik.

Pada umumnya anak-anak usia dini lebih menyukai sesuatu yang unik dan menarik dan indah. Oleh sebab itu agar anak-anak menyukai kegiatan kolase dan tidak kesulitan dalam pembuatan kolase, pendidik atau guru harus dapat menyediakan bahan-bahan yang akan digunakan untuk membuat kolase, yaitu bahan yang disukai anak-anak dan mudah diperoleh. Bahan yang digunakan untuk membuat kolase di sekolah haruslah disesuaikan dengan tingkat perkembangan anak (Widiastini et al., 2014)

Penelitian serupa juga dilakukan oleh (Misiyanti, Parmiti, \& Wirya, 2014) bahwa terjadi peningkatan perkembangan motorik halus dengan penerapan metode demonstrasi berbantuan media konkret melalui kegiatan kolase. Hasil penelitiannya menunjukkan bahwa terjadi peningkatan perkembangan motorik halus yang indikator capaian yaitu : 1) Menggambar bebas dengan berbagai media; 2) Mewarnai bentuk gambar sederhana; 3) Membuat berbagai bentuk dari daun, kertas, kain dan kapas; 4) Membuat mainan dengan tekhnik menempel; 5) Membuat gambar dengan tekhnik kolase dengan memakai berbagai media. Dikatakan kegiatan kolase ini dipilih untuk meningkatkan kemampuan motorik halus karena kegiatan kolase ini dalam pembelajarannya bervariasi dan tidak monoton dan bisa menggunakan media-media yang konkret seperti bahan alam dan bahan-bahan tertentu (Misiyanti et al., 2014) sehingga ini akan semakin membuat anak tertarik dan meningkatkan kemampuan motorik halusnya.

Dari beberapa hasil penelitian yang telah dilakukan maka dapat disimpulkan bahwa kegiatan kolase dapat meningkatkan kemampuan motorik halus anak. Karena melalui kegiatan kolase, anak dapat melatih gerakan-gerakan motorik halus dan koordinasi mata dengan dengan dengan kegiatan yang menarik dan unik. Maka dari itu kegiatan kolase merupakan salah satu kegiatan pembelajaran yang dapat dilaksanakan untuk membantu perkembangan motorik halus anak.

Menurut Sumanto (2005), kolase berasal dari bahasa perancis collage yang berarti merekat. Kolase adalah kreasi aplikasi yang dibuat dengan menggabungkan tekhnik melukis (lukisan tangan) dengan menempelkan bahan-bahan tertentu". Bahan yang digunakan untuk berkreasi kolase tidak hanya terbatas seperti halnya bahan pembuatan mozaik dan montase namun bisa menggunakan aneka jenis bahan alam dan buatan secara bebas baik dilihat dari bentuk, ukuran, maupun jenisnya. Bahan kolase bisa berupa bahan alam, bahan buatan, bahan setengah jadi, bahan jadi, bahan sisa/bekas dan sebagainya.

Jadi dapat hasil penelitian ini dapat disimpulkan bahwa kegiatan kolase dapat mengembangkan kemampuan motorik halus anak, karena dengan kegiatan kolase yang menarik dan unik dengan menyusun, merobek dan menempelkan potongan -potongan benda kecil akan dapat melatih ketelitian anak, kesabaran, kejelian, serta kerapian anak 
dalam membuat hasilnya dengan koordinasi mata dan tangan sehingga anak semakin berkembang motorik halusnya.

\section{Hubungan Kegiatan Kolase dengan Kreativitas Anak Usia Dini}

Dalam pendidikan anak usia dini salah satu aspek yang perlu dikembangkan yaitu kreativitas, karena dengan dikembangkannya kreativitas seorang anak akan memperoleh pengalaman-pengalan dalam menciptakan sesuatu, berimajinasi serta memperoleh hal yang baru, berarti dan bermanfaat.

Seorang anak dapat dikatakan kreatif ialah jika ia telah memenuhi syarat fluency dan flexibility dalam menemukan pemecahan atas sebuah permasalahan. Anak akan memunculkan berbagai ide alternatif yang disebut melakukan fluency. Lebih lanjut anak akan mempertimbangkan solusi yang terbaik. Ketika anak menginginkan sesuatu, maka ia membutuhkan fluency sebagai preparation atau brainstorming. Lalu anak akan melakukan berbagai pemikiran dan pertimbangan, bagaimana agar yang dilakukannya berhasil. Ia akan memilih salah satu alternative solusi yang ada dalam pikirannya. Anak melakukan flexibility karena konteks mulai berbicara. Ternyata, akan terdapat halangan-halangan dalam pelaksanaannya. Jika kemudian anak itu berhasil menyelesaikan masalahnya, maka ia disebut kreatif (Miranda, 2016).

Adapun ciri kreativitas anak usia dini, Munandar (2009:10) menjelaskan ciri-ciri kreativitas yang dibaginya menjadi dua yaitu ciri yang berhubungan dengan kemampuan berfikir kreatif (kognitif) dan ciri yang berhubungan dengan sikap atau perasaan (nonkognitif).

Ciri-ciri yang berhubungan dengan kemampuan berpikir kreatif atau kognitif (aptitude ) antara lain : 1) Keterampilan berpikir lancar, yaitu penyelesaian masalah, pertanyaan, memberikan banyak cara atau saran untuk melakukan berbagai hal serta selalu memikirkan lebih dari satu jawaban; 2) Keterampilan berpikir luwes atau fleksibel, yaitu menghasilkan gagasan, jawaban atau pertanyaan yang bervariasi, dapat melihat suatu masalah dari sudut pandang yang berbeda-beda; 3) Keterampilan berpikir orisinal, yaitu mampu melahirkan ungkapan yang baru dan unik, serta mampu membuat kombinasikombinasi yang lazim dari bagian-bagian atau unsur-unsur. 4) Keterampilan memerinci atau mengelaborasi, yaitu mampu mengembangkan suatu gagasan atau produk, dan menambahkan atau memerinci secara detail dari suatu obyek gagasan, atau situasi sehingga menjadi lebih menarik. 5) Keterampilan menilai, yaitu menentukan patokan penilaian sendiri dan penentuan apakah suatu pertanyaan benar, suatu rencana sehat, atau suatu tindakan bijaksana, mampu mengambil keputusan terhadap situasi yang terbuka, serta tidak hanya mencetuskan gagasan tetapi juga melaksanakannya.

Ciri-ciri yang menyangkut sikap dan perasaan seseorang atau afektif (non aptitude) antara lain adalah : 1) Upaya Rasa ingin tahu, meliputi untuk mengetahui lebih banyak, mengajukan banyak pertanyaan; 2) Bersifat imajinatif, meliputi kemampuan untuk memperagakan; 3) Merasa tertantang oleh kemajemukan, meliputi dorongan untuk mengatasi masalah-masalah yang sulit; 4) Sikap berani mengambil resiko, meliputi keberanian memberikan jawaban meskipun belum tentu benar, tidak takut gagal; 5) Sikap menghargai, meliputi tindakan dapat menghargai bimbingan dan pengarahan dalam hidup, serta menghargai kemampuan dan bakat-bakat sendiri yang sedang berkembang.

Dari ciri kreativitas anak usia dini yang dijelaskan oleh Munandar dapat dikembangan melalui kegiatan kolase. Seperti anak memiliki rasa ingin tahu dari kegiatan kolase karena kegiatan ini menggunakan bahan-bahan yang berbeda sesuai kebutuhan pemakainya, lalu anak akan berusaha memcahkan masalah ketika anak mampu menempelkan bahan kolase sesuai pola, anak akan merasa tertantang dalam menyelesaikan kolasenya dan mampu menghargai hasil karya, bahwa kegiatan kolase sangat meningkatkan kreativitas seorang anak. 
DOI: 10.31004/obsesi.v4i1.347

Sedangkan secara sederhana Hurlock (1978) menginformasikan beberapa faktor yang dapat mendorong seseorang untuk berlaku kreatif, seperti: (1) Waktu (2) Dorongan (3) Kesempatan menyendiri (4) Sarana (5) Lingkungan (6) Cara mendidik (7) Kesempatan untuk memperoleh pengetahuan dan kreatifitas anak dapat dipupuk dengan cara: (1) Merangsang kelancaran, kelenturan dan keaslian dalam berpikir. (2) Memupuk sikap dan minat untuk menyibukkan diri secara kreatif. (3) Menyediakan sarana dan prasarana pengembangan ketrampilan dalam membuat karya yang kreatif.

Dari beberapa pendapat yang telah dipaparkan dapat disimpulkan bahwa faktor yang mendorong seorang untuk berlaku kreatif bisa didapat dari kegiatan kolase, karena dalam kegiatan kolase, anak akan diberi dorongan untuk berimajinasi, disediakan sarana yang menarik untuk anak, berkaitan dengan lingkungan seperti bahan-bahan kolase bisa dari bahan bekas, bahan alam, dll, memupuk rasa ingin tahu anak dengan kegiatannya yang menarik dan unik.

Jadi hasil penelitian ini dapat disimpulkan bahwa kegiatan kolase merupakan salah satu cara ampuh dalam mengembangkan kreativitas pada anak usia dini. Karena secara tidak langsung melalui kegiatan menempel, merobek, menggunting, melipat, mewarnai garigaris, mengisi pola geometri yang dilakukan dapat memberikan dampak positif bagi kemampuan kreativitas anak sehingga dapat menghasilkan sesuatu yang baru, bermanfaat dan inovatif.

\section{SIMPULAN}

Salah satu pekembangan yang harus difasilitasi oleh guru adalah pekembangan motorik halus dan kreativitas. Perkembangan motorik halus ini berkaitan dengan gerakangerakan tangan dan jari-jari yang berkoordinasi dengan mata. Kreativitas juga perlu dikembangkan, karena menjadikan anak lebih kreatif, bisa memecahkan masalah, memberi solusi dan manfaat yang dilakukan melalui kegiatan kolase, karena kegiatan kolase ini suatu kegiatan yang memerlukan konsentrasi, dan berkreasi dalam menyusun dan menempelkan bahan-bahan tertentu. Jadi disimpulkan bahwa perkembangan kemampuan motorik halus dan kreativitas pada anak usia dini memerlukan koordinasi mata dan tangan, seperti menyusun, merobek dan menempel di lakukan dengan kreatif, bermanfaat, unik, menarik melalui kegiatan kolase.

\section{UCAPAN TERIMAKASIH}

Kami sampaikan terima kasih kepada semua pihak yang telah membantu dalam menyelesaikan artikel jurnal ini, mudah-mudahan mendapatkan balasan dari Allah SWT. Aamiin.

\section{DAFTAR PUSTAKA}

Handayani, S., Sumarno, S., \& Suharno, U. (2018). Pengaruh Aktivitas Kolase terhadap Keterampilan Motorik Halus pada Anak Usia Dini melalui Metode Bermain Di TK Pembina Kabupaten Rembang. Seuneubok Lada: Jurnal Ilmu-Ilmu Sejarah, Sosial, Budaya Dan Kependidikan, 5(1), 38-53.

Hurlock, E.B. (1978). Perkembangan anak jilid 1 edisi keenam. Jakarta: Erlangga.

Jamaris, Martini. 2006. Pertimbangan dan Pengembangan Anak Usia TK. Jakarta : Gramedia Widia Sarana Indonesia.

Mayesky, Mary. Creative Art \& Activities: Painting (Kanada: Thomson Delmar Learning, 2004), h. xiv

Miranda, D. (2016). Upaya Guru dalam Mengembangkan Kreativitas Anak Usia Dini di Kota Pontianak. Jurnal Pembelajaran Prospektif, 1(1), 60-67.

Misiyanti, N. W., Parmiti, D. P., \& Wirya, I. N. W. (2014). Penerapan Metode Demonstrasi Berbantuan Media Konkret melalui Kegiatan Kolase untuk Meningkatkan 
DOI: $10.31004 /$ obsesi.v4i1.347

Perkembangan Motorik Halus. Jurnal Pendidikan Anak Usia Dini Undiksha, 2(1).

Muarifah, A., \& Nurkhasanah, N. (2019). Identifikasi Keterampilan Motorik Halus Anak. Journal of Early Childhood Care and Education, 2(1), 14. https:// doi.org/10.26555/jecce.v2i1.564

Mulyadi. 2000. Merangsang Kreativitas Anak dan Kecerdasan Anak. Yogyakarta.

Munandar, Utami. 2004. Pengembangan Kreativitas Anak Berbakat. Jakarta: PT Grasindo

Palintan, A. T. A., \& Saria, S. (2018). Penggunaan media kolase dalam meningkatkan kreativitas anak. Jurnal Al-Athfal Volume, 1(1), 1-9.

Suryana, Dadan. 2018. Stimulasi dan Aspek Perkembangan Anak . Jakarta: Prenadamedia Group Sutama. 2011. Metode Penelitian Pendidikan Kuantitatif, Kualitatif, PTK, R dan D. Surakarta: Fairus Media.

Susanto, Ahmad. 2011. Perkembangan Anak Usia Dini. Jakarta: K encana Prenada Media.

Suarni, Ketut. 2009. Psikologi Perkembangan I. Singaraja: Universitas Pendidikan Ganesha.

Suyanto, S, 2005. Dasar-dasar Pendidikan Anak Usia Dini. Yogyakarta: Hikayat Publishing.

Sujiono, dkk. 2008. Metode Pengembangan Fisik. Jakarta: Universitas Terbuka

Sumanto. 2005. Pengembangan Kreativitas Seni Rupa Anak TK. Jakarta: Depdiknas.

Widiastini, L. P., Raga, G., \& Kusmaryatni, N. (2014). Penerapan Metode Pemberian Tugas Berbantuan Media Bahan Alam untuk Meningkatkan Kreativitas Meronce Anak Kelompok B di TK Nurul Mubin. Jurnal Pendidikan Anak Usia Dini Undiksha, 2(1).

Yulia, Ni Kadek Hari. 2013. Penerapan Model Pembelajaran Explicit Instructon Melalui Kegiatan Bermain Warna Untuk Meningkatkan Perkembangan Motorik Halus Anak Pada Anak Kelompok Bermain Gayatri Denpasar Utara. Skripsi. (tidak diterbitkan) Singaraja: Universitas Pendidikan Ganesha 